\title{
Investigation of Most Commonly Used Instructional Methods in Teaching Chemistry: Rwandan Lower Secondary Schools
}

\author{
Jeannette Musengimana \\ African Center of Excellence for Innovative Teaching and Learning of \\ Mathematics and Science (ACEITLMS), \\ University of Rwanda College of Education (URCE), Rwanda \\ https://orcid.org/0000-0002-3553-0592 \\ Edwige Kampire \\ University of Rwanda College of Education (URCE), Rwanda \\ https://orcid.org/0000-0002-7410-6508 \\ Philothère Ntawiha \\ University of Rwanda College of Education (URCE), Rwanda \\ https://orcid.org/0000-0002-5817-229X
}

\begin{abstract}
Improved teaching methods facilitate the ease of acquisition of knowledge and lead to better achievement. The present study investigates the instructional methods most commonly used in teaching chemistry in lower secondary schools in Rwanda. SPSS 23.0 was used to analyze data from a survey conducted on 51 lower secondary chemistry teachers. The survey has satisfactory and acceptable reliability (Cronbach alpha $=0.913$ for 57 items on average). The results revealed that teachers prefer active learning methods though they still use traditional teaching methods. Comparison of teachers' responses in terms of experience showed no statistically significant difference with $p=$ 0.064 . The study also found that some teachers have misconceptions in differentiating instructional approaches, methods, and techniques or strategies. Therefore, it is recommended that educational stakeholders should plan pieces of training to teachers about different instructional methods and techniques to use in chemistry teaching for effective learning outcomes.
\end{abstract}

Keywords: chemistry lesson; Instructional methods; Rwandan schools; survey questionnaire 


\section{Introduction}

Chemistry knowledge is used as a pre-requisite to study any science-related field or other technology-related disciplines such as medicine, pharmacy, engineering, agriculture, veterinary, to mention a few. Therefore, it is introduced in secondary schools' curriculum due to its relevance to society and educational value among individuals. To this end, the improvement in the teaching strategy used in chemistry teaching that facilitates the easy acquisition of knowledge which leads to a better achievement is recognized (Alabi, 2014). Teaching is effective when the instructional approach used in the teaching and learning process induces a desirable change in the learner's behavior. Hence, if improvement in the students' achievement is needed, there is a necessityto introduce effective, efficient, and appropriate teaching approaches (Jack, 2013). This is related to the fact that the teaching methods are worldwide recognized to occupy a top position as factors affecting students' achievement in secondary school subjects, chemistry included.

\section{Research Problem}

The main goal of chemistry education is to develop active students in the learning process through the appropriate instructional approaches. In line with this, Rwanda's educational system moved from a Knowledge-Based Curriculum (KBC) to a Competency-Based Curriculum (CBC) since 2016, which involves the active participation of learners in the learning process. Recent studies have been carried out to investigate the implementation of this new curriculum. It has been confirmed that even though the Rwandan government has put more effort so far to train teachers on active learner-centered methods, traditional approaches centered on teachers and directed by teachers are still used by most science teachers (Ndihokubwayo et al., 2020). In addition, many teachers use group work activities to practice $\mathrm{CBC}$, which centered on learners, bearing in mind that grouping students favor active participation. However, this was not the case as they only engage students in small group work activities, sometimes limited to a question and answer session. This provides no knowledge construction among students as they remain passive in the learning process (Byusa et al., 2020a; Nsengimana et al., 2017). The inability of teachers to use appropriate methods of instruction to teach chemistry that invariably translate to inadequate knowledge and skills to put in practice the learned material is becoming a challenge to the Rwandan educational system. Moreover, the presence of mixed ability among students, makes hard for teachers to take into consideration the need of every student. However, they are supposed to adapt and develop teaching methods based on their needs (Kousa et al., 2018). Also, the shortage of suitable teaching materials, especially in day schools, particularly nine years of basic education schools, constitutes the biggest challenge (Nsengimana et al., 2021; Nsengimana, 2021).

It is worth noting that several instructional methods that promote active learning are put in place to favor the implementation of $\mathrm{CBC}$. These include inquiry-based learning, co-operative learning, problem-based learning, activitybased learning, and instructional-based learning, among others. However, there is a deficiency of substantial studies carried out to investigate whether chemistry 
teachers prefer to use the active methods mentioned above .Therefore, there is a need to investigate whether these methods are being employed by teachers and find out the level at which they improve students' competent areas like conceptual understanding, achievement on tests and exams, attitudes toward chemistry, critical thinking skills, problem-solving skills, creativity and innovation, collaboration skills, participation, lifelong learning skills, ability to conduct research, among others.

This study is designed to fill in the gap about the most used methods preferred by teachers, and it provides insights into how students gain competent skills. Educational stakeholders may use the findings of this paper to address the needs of teachers and hence build the quality of chemistry education. Specifically, it seeks to answer the following research questions:

1. What are the most instructional methods preferred by chemistry teachers in teaching chemistry in lower secondary schoolsin Rwanda?

2. Which areas (conceptual understanding, achievement on tests and exams, attitudes toward chemistry, critical thinking skills, problemsolving skills, creativity, and innovation, collaboration, participation, research skills, and classroom management) do teachers perceive can be improved by these methods?

3. To what extent does the utilization of the instructional methods differ across teachers' experiences?

\section{Literature Review}

Several studies have acknowledged the benefits of instructional methods on students' achievement (Aidoo et al., 2016; Gabel, 1999; Khan et al., 2011; Kousa et al., 2018; Yunus \& Ali, 2018; Yusuf, 2004). For example, the effect of cooperative learning instruction on students' academic achievement has been found to increase the achievement level of students (Olatoye et al., 2011; Yusuf, 2004). In a study conducted on $11^{\text {th }}$-grade students to investigate the effect of cooperative learning instruction, it was found that students who were taught using co-operative learning instruction had a significantly higher score in the achievement test carried on electrochemistry topic than those who were trained using a traditional approach (Acar \& Tarhan, 2007). A further study which was carried out among senior secondary school students to examine the influence of co-operative learning teaching strategy indicated that this method of instruction reduced the level of anxiety in learning chemistry drastically, while those treated with conventional-lecture (chalk and talk method) their level of anxiety was increased (Oludipe \& Awokoy, 2010). Due to the effectiveness of cooperative learning methods in reducing students' anxiety in chemistrylearning, teachers are encouraged to incorporate co-operative learning instructional into their teaching methods.

The virtual laboratory was found to effectively affect students' achievement in the same way as the real chemistry laboratory (Gabel, 1999). Tatli and Ayas (2013), in their study that examined the effect of virtual chemistry laboratory on students' achievement in the chemical changes unit, argued that this method is found to be as effective as the real chemistry lab. Tuysuz (2010) found a similar 
finding, in which the result showed a positive effect of the virtual laboratory on

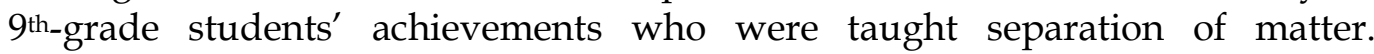
Students who received treatment through the virtual laboratory were successful over the ones treated with the traditional chalk and talk method. In a study conducted in Malaysia, descriptive research was employed on students aged 1516 years old to investigate the factors affecting students' attitudes towards chemistry. It was found that the majority of the students $(85 \%)$ developed a positive attitude when they conduct chemistry experiments in the laboratory (Yunus \& Ali, 2018). In the same line of thought, Akani(2015) investigated the relationship between laboratory instruction, attitude toward chemistry, and achievement. The study revealed that regular laboratory instruction directly influences academic achievement.

Problem-Based Learning (PBL) is another instructional method commonly used in learning chemistry. Its effect on students' achievement has been extensively studied by different researchers. For instance, Aidoo et al. (2016) found a significant difference in students' achievement using PBL instruction and those taught using a traditional instructional approach. In line with this, Abanikannda (2016) indicated that students' academic achievement exposed to PBL has improved as well as their perception of chemistry has changed. Furthermore, the analysis of covariance of students' mean achievement scores was conducted to investigate the effect of problem-based and discovery-based instructional strategies on students' academic achievement in chemistry. The result showed that problem-based strategies significantly increased the achievement level of students more than the discovery-based and expository strategies (Anyafulude, 2013).

Inquiry-based teaching strategy has also been discussed as the learner-centered method, which facilitates the active participation of students (Khan et al., 2011). The method provides a higher degree of thinking, a deeper understanding of the concept, and practical skills. Also, the effect of inquiry-based approaches to teaching students' academic achievement has been studied. It was found that students taught using inquiry-based instruction achieved higher than those taught using traditional instruction ( Abdi, 2014; Khan et al., 2011). Besides, students can learn more effectively when they are taught using an instructional design that matches their learning styles (Kanadli, 2016). Therefore, teachers need to choose the instructional methods suited to their students to improve their academic achievement, attitude, and retention towards the subject being taught.

Concept mapping also has been proved to be an effective teaching strategy that improves students' achievement and retention time (Chawla \& Gurmit, 2015; Jack, 2013; Olarewaju \& Awofala, 2011; Sing \& Moono, 2015). A concept map is regarded as a diagram that shows relationships among concepts. While using a concept map, knowledge is organized and represented in a two-dimensional, visually based representation through which concepts are being represented graphically. It is, therefore, the instrument that helps in organizing and structuring knowledge.Furthermore, concept mapping is an effective teaching 
strategy due to its significant advantage of consolidating and precise understanding of science concepts and making inter-relations between two or more concepts (Jack, 2013). It also helps students develop abilities to solve problems and find solutions to questions requiring application and synthesis of concepts (Olarewaju \& Awofala, 2011). This teaching method helps students actively construct an understanding of concepts, thereby making connections between variables of interest in a given subject. It supports learners' effort to conceptualize their knowledge into visually apparent graphical tools that connect the existing concepts with the newly acquired concepts (Sing \& Moono, 2015). Thus, it makes the learning process more active rather than being passive. Therefore, the concept maps are beneficial in the teaching and learning process as the use of maps helps develop a long-lasting impression among students' memory and retention time, hence improving their learning outcomes (Chawla \& Gurmit, 2015).In addition, concept maps have been used to observe changes in students' understanding of concepts over time. The observer has to elaborate on the conceptual understanding that students possess and then build on them to recognize and modify those containing alternative conceptions or misconceptions (Olarewaju \& Awofala, 2011). In this respect, it is considered a key to organizing an excellent and effective knowledge base as it leads to greater achievement when used in the learning process. However, the method is recommended as an effective teaching instruction in science education.

The effect of web-based computer simulation has been investigated. Besides increasing students' attitudes towards chemistry and academic achievement (Olakanmi, 2008), web-based instruction also helps develop generic competency skills. These include critical thinking and problem-solving skills, creativity and innovation, and research skills among higher secondary students (Frailich et al., 2007; Sudha \& Amutha, 2015). In education, WBI is becoming more important. In other words, it renders the learning environment more interesting, meaningful, and very effective since it provides an opportunity for students to be exposed to multisensory experiences (Sudha \& Amutha, 2015). The most current information in the form of modeling, simulations, and visualization, tools are made available to students to facilitate them analyzing and examining the online materials and increasing the conceptual understanding of science (Frailich et al., 2007). Its effect on students' achievement has also been studied. It has been indicated that the use of WBI helps higher secondary schools' students improve their learning capacity in chemistry and hence their achievement (Sudha \& Amutha, 2015). It was also found that WBI plays a crucial role in enhancing the comprehension of chemistry concepts, the attitudes and interests of students, and students' awareness, emphasizing the relevance of chemistry to daily life (Frailich et al., 2007).

\section{Methodology}

\subsection{Research Design}

A survey research design guided the present study. The survey study is conducted to obtain data from a given population or a sample to determine the attitudes, opinions, beliefs, characteristics of members of that population (Fraenkel et al., 2012). In this research, quantitative data were collected using a 
questionnaire to identity the instructional methods used by teachers while teaching chemistry.

\subsection{Sampling Technique}

A snowball technique, a non-probability sampling technique, was used as a sampling procedure (Ndayambaje, 2018). This is because the participants were not reachable due to the COVID-19 pandemic as traveling and meeting people were restricted by the government to avoid the spread of the pandemic. The study dealt with 51 chemistry teachers located in different districts. The participants were accessed by sharing a link of the survey questionnaire to one teacher in the Gasabo district and another from the Rwamagana district. The target area of this study included the two districts. The two teachers were asked to complete the survey and share the same link with their respective groups through WhatsApp. Therefore, teachers from different districts apart from Gasabo and Rwamagana districts participated in the survey as the link was shared online. Hence, their responses were also considered. Table 1 summarizes the characteristics of the sample used in this study.

Table 1: Sample Characteristics

\begin{tabular}{|c|c|c|c|c|c|c|c|c|c|}
\hline \multicolumn{2}{|c|}{ Gender } & \multicolumn{2}{|c|}{ Age range } & \multicolumn{2}{|c|}{ Type of School } & \multicolumn{2}{|c|}{ Year of experience } & \multicolumn{2}{|c|}{ District } \\
\hline Male & $76 \%$ & $1970-1979$ & $4 \%$ & Public & $90 \%$ & $0-1$ & $18 \%$ & Kayonza & $18 \%$ \\
\hline Female & $24 \%$ & 1980-1989 & $59 \%$ & Private & $10 \%$ & $2-3$ & $20 \%$ & Rwamagana & $35 \%$ \\
\hline & & 1990-1999 & $37 \%$ & & & $4-5$ & $6 \%$ & Gasabo & $20 \%$ \\
\hline & & & & & & $6-9$ & $37 \%$ & Nyarugenge & $2 \%$ \\
\hline & & & & & & $10-19$ & $18 \%$ & Nyamasheke & $14 \%$ \\
\hline & & & & & & over 20 & $2 \%$ & Ruhango & $2 \%$ \\
\hline & & & & & & & & Nyaruguru & $2 \%$ \\
\hline & & & & & & & & Gisagara & $2 \%$ \\
\hline & & & & & & & & Burera & $2 \%$ \\
\hline & & & & & & & & Gicumbi & $2 \%$ \\
\hline & & & & & & & & Karongi & $2 \%$ \\
\hline Total & $100 \%$ & & $100 \%$ & & $100 \%$ & & $100 \%$ & & $100 \%$ \\
\hline
\end{tabular}

\subsection{Instrument Preparation, Validity, and Reliability}

The teachers' survey questionnaire was used to investigate the instructional methods commonly applied in the teaching and learning of chemistry in lower secondary schools. From the consulted literature and daily experience, a survey of two parts, one with 56 statements and six questions, was prepared. This was shared with $4 \mathrm{Ph}$.D. students for face validity. They were asked to examine each question in the survey to see whether the question intends to measure what is supposed to be measured, whether it is clear, coherent, relevant, and to confirm whether the whole questionnaire is sufficient and check its objectivity. Based on the comments provided by the Ph.D. students, ten non-clear statements were removed in part one and two questions in part two, while others were reformulated. The remaining 46 statements in part one and three questions in part two represent the final survey. The statements were classified into five concepts (planning, instructional methods, classroom environment, assessment, 
and encouragement). The planning process, lesson delivery through which you implement your instructional methods, classroom environment, the way you assess students, and the kind of motivation provided to students contribute more to the choice of instructional method. For this questionnaire, the above five concepts were chosen to explore the most preferred instructional methods. The questionnaire was content validated by two expert university lecturers and one Ph.D. student. Therefore, it was converted to an online form using Microsoft form, a link of it was created and shared through WhatsApp.

A pilot study was conducted to check if the designed questionnaire is reliable. The questionnaire was administered to 22 teachers of lower secondary schools. The link was given to some chemistry teachers and asked them to complete the survey. Furthermore, they were also asked to share the same link with their respective fellows. Hence, 22 teachers located in different districts participated in the pilot study. Computing Cronbach alpha was found to be 0.364, 0.779, $0.653,0.514,0.06$, and 0.935 for planning, instructional methods, classroom environment, assessment, encouragement, and area of improvement, respectively. The overage was 0.913 for 57 items. This showed that the survey has satisfactory and acceptable reliability. The final survey questionnaire consisted of 46 items located in part one in which teachers were asked to rate the extent to which they strongly agree, agree, undecided, disagree, and strongly disagree on each of the proposed statements related to the most common instructional methods used in the teaching and learning of chemistry. The items located in part two intended to ask the teachers to state the most preferred teaching method when teaching chemistry and to give a reason that justifies their preferred method of teaching; they were requested to rate the areas of improvement provided by giving a rough estimate from 1 to 5 where five = much improved and one = least improved. In addition, teachers were asked if they have ever been trained on different teaching methods, if yes, what were these methods, and if no, they were asked to suggest different methods that they would like to be trained on to improve their chemistry teaching.

\subsection{Data Analysis}

Data from the pilot study was compiled and analyzed using a computerized data analysis package known as Statistical Package for Social Science (SPSS 23) to determine the reliability. Descriptive statistics such as "countif" and percentages calculated using Excel 2016 were also used to analyze raw data from chemistry teachers. Inferential statistics (Chi-square test) calculated using SPSS was used to determine to what extent does the utilization of the instructional methods differs across teachers' experiences. As the survey was online, the teachers' responses were opened in excel format, and they were assigned numbers to strongly agree (5), agree (4), undecided (3), disagree (2), and strongly disagree (1) for ease of analysis. To determine the numbers of teachers who agreed, were undecided, or disagree with the proposed statements, three analysis scales were formed instead of five by combining 1 and 2 for disagreed options, 4 and 5 for agreeing options, and three remained for undecided. The COUNTIF formula was applied to determine how many teachers agreed, disagreed, or were undecided for a given statement and, then their percentage 
was determined. Similarly, numbers 1 and 2 were combined to mean the least improved areas and numbers 4 and 5 to mean the much-improved areas while determining the areas of improvement that justify teachers' preferred methods. For the items where teachers had to give answers, their responses were counted manually.

\section{Results and Discussion}

Statements to investigate the most commonly used instructional methods were classified into four concepts. This is because the instructional methods cannot bring the desired outcomes among students. Therefore, teachers are involved in the way they plan their lessons before their delivery, how they organize their classroom environment, how they assess as well as the way they encourage or motivate students in the learning process (Nsengimana et al., 2020). Hence, a statement in each concept helped to distinguish the type of instructional methods being used by the teacher.

\subsection{Planning}

Statements 1, 4, 5, 6, and 7 indicated that teachers used the active learning methods while implementing $\mathrm{CBC}$ as above $90 \%$ of them agree to the statements. Statements 2 and 3 indicated passive learning methods, and $82 \%$ and $79 \%$-of teachers respectively disagreed to the statements (see Table 2).

Table 2. Teachers' Perception on Planning

\begin{tabular}{|c|c|c|c|c|}
\hline & Statements & $\begin{array}{c}\text { Agr } \\
\text { ee } \\
(4)\end{array}$ & $\begin{array}{l}\text { Undeci } \\
\text { ded (3) }\end{array}$ & $\begin{array}{l}\text { Disagr } \\
\text { ee }(2)\end{array}$ \\
\hline 1 & $\begin{array}{l}\text { I plan activities to prove that particular competency } \\
\text { has been mastered by the learner }\end{array}$ & $98 \%$ & $0 \%$ & $2 \%$ \\
\hline 2 & $\begin{array}{l}\text { I only use notes found in the book without making my } \\
\text { summary as it requires much time }\end{array}$ & $14 \%$ & $4 \%$ & $82 \%$ \\
\hline 3 & $\begin{array}{l}\text { I use old notes that were used previously in the } \\
\text { teaching of chemistry }\end{array}$ & $16 \%$ & $6 \%$ & $79 \%$ \\
\hline 4 & I plan my lesson prior to its delivery & $96 \%$ & $2 \%$ & $2 \%$ \\
\hline 5 & $\begin{array}{l}\text { While planning, I set clear instructional objectives and } \\
\text { integrate cross-cutting issues into my lesson plan }\end{array}$ & $98 \%$ & $0 \%$ & $2 \%$ \\
\hline 6 & $\begin{array}{l}\text { I plan activities that help to evaluate students' } \\
\text { acquired competences }\end{array}$ & $98 \%$ & $0 \%$ & $2 \%$ \\
\hline 7 & $\begin{array}{l}\text { I use cognitive terminology such as classify, analyze, } \\
\text { predict, and create while framing tasks }\end{array}$ & $90 \%$ & $6 \%$ & $4 \%$ \\
\hline
\end{tabular}

The results from Table 2 showed that there are teachers who still implement the use of passive methods of teaching. They do not plan their lessons rather, they rely on the old notes used in the previous years, or they copy them directly from a textbook without summarizing them. Teachers argued that it takes more time to plan while they have a heavy workload. Ndihokubwayo et al. (2020) found similar results in their study where physics teachers are found to use the effective active learning methods unwillingly, and their lesson plans do not well reflect on the competence-based curriculum.

\subsection{Instructional Methods}


Statements 1, 2, 3, 10, and 17 reflect the passive teaching methods in which teachers use lecturing, authoritative, knowledge-based, and teacher-led demonstrations. For instance, $71 \%$ of teachers agreed to explain the concepts verbally and provide notes later, 59\% agreed that they are the ones to decide on the topic to be covered, $63 \%$ agreed to transfer knowledge to students and expect them to recall everything. In comparison, 39\% also agreed that they mostly use the chalk and talk method as it helps them cover many topics in a limited amount of time (Table 3a).

Table 3a: Teachers' Perception on Instructional Methods

Statements

In my class, I give explanations of the concepts verbally and provide notes later

2

In my teaching practice, I mostly use the chalk and talk method as it helps me to cover many topics in a limited amount of time

I decide on the topic to be covered in my class

I involve my students in a group discussion in my class about efficient learning experiences rigorously. each other

\section{I apply learner-centered methods as they help me to} complete the scheme of work

I let my students learn through the completion of meaningful tasks. everything

$$
\text { I prefer to use the inquiry method to make learners }
$$
discover the new knowledge

I use demonstrations to make the lesson more understandable

In lab, I allow students to carry hands-on activities (experiments)

I use simulated experiments than conducting practical works in the laboratory observe but not allowing them to practice their own experiments

In my class, I use hands-on activities

I use web-based instruction to promote coherent conceptual understanding

I take my students outside the classroom for field trips
I let students decide on the topic to be covered in my class

I engage my students to participate in activities that bring

I let my students learn in a small group with the help of

I transfer knowledge to students and expect them to recall

I give each student a task to accomplish during the lesson

I prefer computer simulation to clarify the abstract concept

When I carry out the experiment, I only ask students to
$79 \% \quad 10 \% \quad 12 \%$
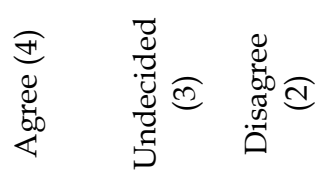

$71 \% \quad 10 \% \quad 20 \%$

$39 \% \quad 8 \% \quad 53 \%$

$59 \% \quad 14 \% \quad 27 \%$

$36 \% \quad 20 \% \quad 45 \%$

$100 \% \quad 0 \% \quad 0 \%$

$92 \% \quad 2 \% \quad 6 \%$

$92 \% \quad 4 \% \quad 4 \%$

$78 \% \quad 8 \% \quad 14 \%$

$92 \% \quad 6 \% \quad 2 \%$

$63 \% \quad 6 \% \quad 31 \%$

$90 \% \quad 6 \% \quad 4 \%$

$90 \% \quad 4 \% \quad 6 \%$

$81 \% \quad 10 \% \quad 10 \%$

$78 \% \quad 8 \% \quad 14 \%$

$72 \% \quad 14 \% \quad 14 \%$

$55 \% \quad 20 \% \quad 26 \%$

$16 \% \quad 6 \% \quad 78 \%$

$69 \% \quad 18 \% \quad 14 \%$

$69 \% \quad 10 \% \quad 22 \%$ 
These findings implied that the practice of the teacher-centered method is still dominating in some schools. The results are supported by Uwizeyimana et al. (2018), who similarly argued that traditional teacher-centered methods are still observed in the teaching of physics. From other studies conducted by Makunja (2016); Nsengimana (2021) revealed that most of the teachers reported the challenges they face while implementing the CBC. These include the unavailability of adequate and effective teaching and learning materials, students' readiness to practice learner-centred methods, and low ability of students joining secondary classes. These hinder the effective teaching and learning of science in general and that of chemistry. In addition, some content of the $\mathrm{CBC}$ requires materials that cannot be improvised, and hence, they are taught theoretically. Furthermore, teachers argued that the overloaded timetable of 35 to 40 hours per week and the increased number of students (60 students and above per class), especially at the ordinary level, do not allow them to put into practice all the methodology suggested by $\mathrm{CBC}$, the reason why traditional means of teaching are still used.

The other statements revealed active instructional methods, which involve techniques like group discussion, activity-based, peer learning, hands-on activity, web-based, field trip, virtual experiment. Group discussion was rated more $(100 \%)$ by all teachers (see Table $3 a)$. The findings are incongruent with that of Byusa et al. (2020b). This is because all these techniques are involved in the implementation of $\mathrm{CBC}$ to emphasize the learner-centered method. As most of the teachers have been trained on the implementation of $\mathrm{CBC}$, they pretend to use the active teaching methods as a requirement of $\mathrm{CBC}$ when they are asked anything to do with the teaching practice.

The statements from the instructional methods were classified into two themes: Passive and active teaching methods; then they were further classified into different teaching techniques (Table $3 b$ ). It was found that the most preferred methods are active methods involving teaching techniques such as: group discussion, activity-based, peer learning-based, hands-on activity, virtual experiment, etc.).

Table 3b: Most Preferred Instructional Methods

\begin{tabular}{|c|c|c|c|}
\hline $\begin{array}{l}\text { Main teaching } \\
\text { philosophy }\end{array}$ & $\begin{array}{l}\text { Main teaching } \\
\text { methods/approaches }\end{array}$ & Teaching techniques & $\begin{array}{l}\text { Items in a survey } \\
\text { related to } \\
\text { instructional methods }\end{array}$ \\
\hline $\begin{array}{c}\text { Learners } \\
\text { centeredness }\end{array}$ & Active learning & $\begin{array}{c}\text { Participative } \\
\text { Group discussion } \\
\text { Peer learning } \\
\text { Activity-based } \\
\text { learning } \\
\text { Task-based learning } \\
\text { inquiry-based } \\
\text { learner demonstration } \\
\text { Virtual experiment } \\
\text { Hands-on activity } \\
\text { web-based } \\
\text { Field-trip }\end{array}$ & $\begin{array}{c}4,8 \\
5 \\
7 \\
6 \\
9,13 \\
11 \\
12 \\
14,16 \\
15,18 \\
19 \\
20\end{array}$ \\
\hline
\end{tabular}




\begin{tabular}{cccc}
\hline Teacher & Passive learning & Lecturing & 1,2 \\
centeredness & Authoritative & 3 \\
& & knowledge-based & 10 \\
& & teacher demonstration & 17 \\
\hline
\end{tabular}

The results of this study showed that lower secondary school teachers are aware of the active instructional methods. This is attributed to the shift from Knowledge-Based Curriculum (KBC) to Competence-Based Curriculum (CBC). Most of the teachers have been trained on the methods of instruction required to implement CBC.The findings are in line with those of Byusa et al. (2020) through the survey, self-reported questionnaire, and interview for teachers. They indicated that S2 chemistry teachers claimed to use active learning daily as a requirement in the implementation of $\mathrm{CBC}$. However, it is not the case by using the COPUS tool for classroom observation. The observed teachers were found to use lecturing methods, write notes on the board, and put students into a small group to discuss a small activity that does not engage learners in knowledge construction. Thus, the real classroom practice did not reflect the actual active teaching approaches, which was also different from what teachers respond to through interviews and surveys.

\subsection{Classroom Environment}

The classroom environment is another concept that was tackled in this study. Teachers' perceptions on how they manage their students were all agreed over $80 \%$. For instance, they agreed $100 \%$ to the statement like I guide and facilitate my students in the learning process (statement 2). When I introduce a new topic, I consider students' prior knowledge (statement 3) (Table 4). All these reflect the practice of the learner-centered method.

Table 4: Teachers' Perception on Classroom Environment

\begin{tabular}{|c|c|c|c|c|}
\hline & Statements & 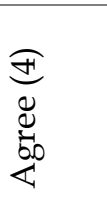 & 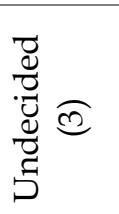 & 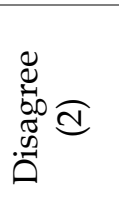 \\
\hline 1 & I make correction of exercises on the board & $94 \%$ & $4 \%$ & $2 \%$ \\
\hline 2 & $\begin{array}{l}\text { I guide and facilitate my students in the learning } \\
\text { process }\end{array}$ & $100 \%$ & $0 \%$ & $0 \%$ \\
\hline 3 & I like working with my students in all activities & $84 \%$ & $4 \%$ & $12 \%$ \\
\hline 4 & $\begin{array}{c}\text { When I introduce a new topic, I consider students' } \\
\text { prior knowledge }\end{array}$ & $100 \%$ & $0 \%$ & $0 \%$ \\
\hline 5 & I help my students to reach me whenever they want. & $82 \%$ & $10 \%$ & $8 \%$ \\
\hline 6 & $\begin{array}{c}\text { I ask many questions to students to develop their } \\
\text { critical thinking skills }\end{array}$ & $98 \%$ & $0 \%$ & $2 \%$ \\
\hline 7 & $\begin{array}{l}\text { I openly share with my students if there is something I } \\
\text { do not know }\end{array}$ & $80 \%$ & $6 \%$ & $14 \%$ \\
\hline 8 & I share with my students the objectives of the lesson & $90 \%$ & $4 \%$ & $6 \%$ \\
\hline 9 & $\begin{array}{l}\text { I allow students to use a variety of means such as } \\
\text { diagrams, models, graphs, drawings, or any } \\
\text { manipulative material to represent the phenomena }\end{array}$ & $92 \%$ & $2 \%$ & $6 \%$ \\
\hline 10 & $\begin{array}{c}\text { I allow my students to organize a debate on a } \\
\text { particular topic }\end{array}$ & $84 \%$ & $8 \%$ & $8 \%$ \\
\hline
\end{tabular}


The findings were not far from the ideas of Hailikari et al. (2008), who acknowledged the benefits of considering the prior knowledge of the students. Their findings showed that students' prior knowledge should be considered while designing instruction methods and curriculum planning. This is because prior-knowledge assessment might be used to identify students who are struggling with some concepts. It helps the teacher to recognize the appropriate level at which s/he can start the lesson, which method could be used to address the different levels of difficulties, and identify how to group students according to their ability. Statement one (I make correction of exercises on the board) revealed the passive learning methods which is centered on the teacher. It showed that teachers are the ones to correct exercises instead of giving time to students to correct them and facilitate them. However, many teachers agreed on the statement (above 90\%). This clearly showed that, even though teachers claim to use active learning methods, they still apply some passive teaching methods (Byusa et al., 2020a; Suhag et al., 2018)

\subsection{Assessment}

The results summarized in Table 5 indicated that teachers engage students in the learning process by assigning them many works. For illustration, $98 \%$ of teachers assign students researches and homework while $96 \%$ probe many examples from students to prove their understanding of the concept taught.

Table 5: Teachers' Perception on Assessment

\begin{tabular}{|c|c|c|c|c|}
\hline & Statements & 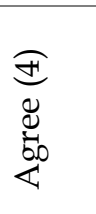 & 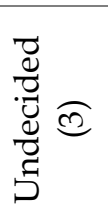 & 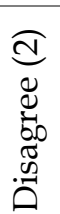 \\
\hline 1 & $\begin{array}{l}\text { I expect my students to do exercises on their } \\
\text { own }\end{array}$ & $88 \%$ & $6 \%$ & $6 \%$ \\
\hline 2 & I assign students researches as homework & $98 \%$ & $0 \%$ & $2 \%$ \\
\hline 3 & $\begin{array}{l}\text { I expect my students firstly solve the problem } \\
\text { on their own }\end{array}$ & $90 \%$ & $6 \%$ & $4 \%$ \\
\hline 4 & I ask many examples from my students & $96 \%$ & $2 \%$ & $2 \%$ \\
\hline
\end{tabular}

Proper and effective assessment for the learning process promote the active engagement of learners (Rawlusyk, 2018). Also, students' ability to learn and the quality of learning are influenced by how the learning process is assessed (Stiggins, 2002). In this study, it was found that teachers were agreed to all statements that help to recognize how they assess their students. Teachers ask questions that allow students to actively participate in the assessment and hence facilitate and strengthen their learning process. They try to ask questions which develop the spirit of research among their students, critical thinking skills, and problem-solving skills. Therefore, students keep learning as well as assessment is continuous, and they continue to learn progressively at productive levels if they do not give up in frustration or hopelessness, as supported by Stiggins (2002). 


\subsection{Encouragement}

According to the results from Table 6, it is also observed that many teachers encourage their students to be involved in the learning process. For instance, $100 \%$ of the teachers encourage students to conduct research on a given problem, and $100 \%$ of teachers encourage students to be involved in each activity taking place in chemistry lessons.

Table 6: Teachers' Perception on Encouragement

\begin{tabular}{|c|c|c|c|c|}
\hline & & 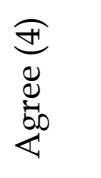 & 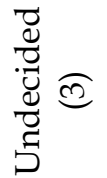 & 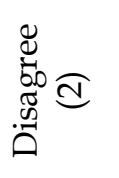 \\
\hline 1 & $\begin{array}{l}\text { I encourage my students to make a research on a } \\
\text { given problem }\end{array}$ & $100 \%$ & $0 \%$ & $0 \%$ \\
\hline 2 & $\begin{array}{l}\text { I motivate them to produce new projects by } \\
\text { applying the knowledge gained }\end{array}$ & $96 \%$ & $2 \%$ & $2 \%$ \\
\hline 3 & $\begin{array}{l}\text { I encourage students to be involved in each activity } \\
\text { taking place in the chemistry lesson }\end{array}$ & $100 \%$ & $0 \%$ & $0 \%$ \\
\hline 4 & $\begin{array}{l}\text { I encourage students to copy notes from the } \\
\text { blackboard }\end{array}$ & $74 \%$ & $14 \%$ & $12 \%$ \\
\hline 5 & $\begin{array}{c}\text { I motivate my students by providing incentives to } \\
\text { the best performer in class }\end{array}$ & $79 \%$ & $18 \%$ & $4 \%$ \\
\hline
\end{tabular}

The encouragement and kind of motivations teachers provide to their students play a crucial role in their willingness to study (Alcott, 2017). This is felt in statement 1(I encourage my students to do research on a given problem) and 3(I encourage students to be involved in every activity taking place in the chemistry lesson) in which teachers rated them up to $100 \%$. This means that they encourage their students to be involved in their learning process by finding a solution to the given problem and being engaged in every activity in the classroom, and redirecting the active learning method.

Statement 4 (I encourage students to copy notes from the blackboard) encourages students to copy notes from the blackboard, which is the passive teaching method. Only $12 \%$ of teachers disagreed with this statement; $74 \%$ agreed, and 14 $\%$ were undecided about this statement. This showed that many teachers still rely on the traditional teaching methods, allowing students to copy notes from the blackboard. This is a purely passive learning method in which teachers act as knowledge transfers and students act as knowledge receivers.

When teachers were asked to state their most preferred chemistry teaching method, some of their responses are represented in Figure 1: 


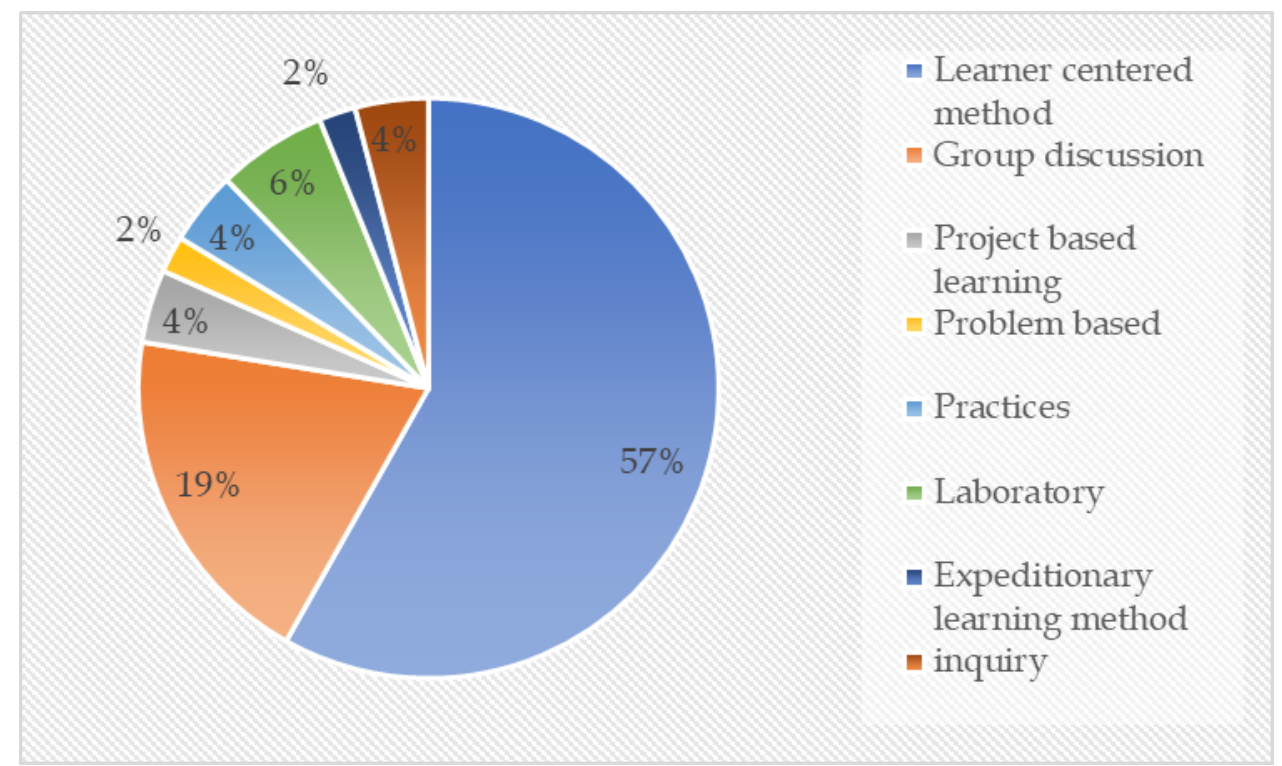

Figure 1: Teachers' Responses on the Most Preferred Chemistry Teaching Methods.

Most teachers (57\%) indicated that they use the learner-centered method. 19\% revealed that they use group discussion. In comparison, others use laboratory or carrying experiment in the laboratory (6\%), Project-Based learning and the use of practices rated at $4 \%$ each, and problem-based learning and expeditionary learning was rated at $2 \%$ each. These findings implied that most teachers (57\%) have a misconception in differentiating teaching approaches, methods, and teaching techniques. For instance, learners-centered methods constitute a teaching approach rather than a method. It involves different teaching methods like problem-based learning, inquiry-based learning, co-operative-based learning, concept-based learning, among others. The approach is regarded as the view of looking at things. It involves the procedure of teaching-learning or of the way we teach (Gill \& Kusum, 2017). Examples of learning approaches include the teacher-centered approach and learner-centered approaches. A method is a pedagogical term used to describe the practical realization of an approach. It is concerned with effective presentation of the subject matter occurring step by step, thereby enhancing its mastery. The teaching method is the formal structure of presenting the content in the classroom known as teaching instructions (Gill \& Kusum, 2017). Examples of teaching methods are lecture, demonstration, discussion, question-answer, project, and problem-solving methods, among others. The technique is simply the way of carrying out a particular task. It means how a teacher teaches, or how s/he teaches, is referred to as a teaching technique. It involves a series of steps teachers use to implement a method.

Furthermore, when teachers were asked to rate the levels at which the proposed areas have been improved while using their preferred methods, they showed that classroom management (statement 11 ) rated at $78 \%$ was highly improved compared to other areas (Figure 2). Probably, this may be attributed to the fact that due large classroom size encountered in most schools, teachers struggle to manage those big classes by using teaching techniques that provide a holistic learning environment. 


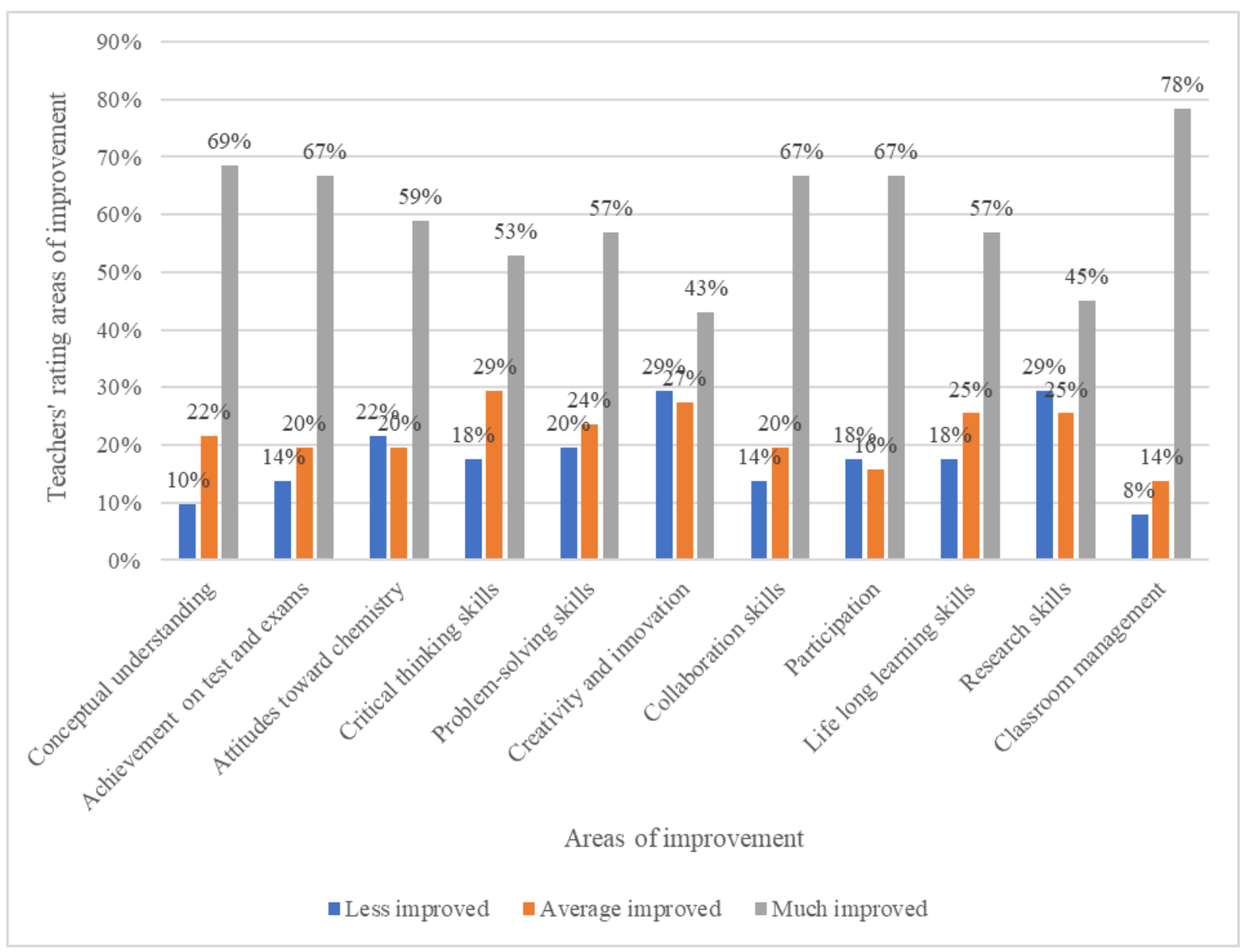

Figure 2: Teachers' Rating Areas of Improvement.

Statements 1, 2, 7, and 8 representing students' conceptual understanding, students' achievement on tests and exams, students' collaboration skills, and students' participation, respectively, were moderately improved. Teachers rated them at $69 \%, 67 \%, 67 \%$, and $67 \%$ (Figure 2). The moderate improvement can be due to the limited time allocated to each period which is not enough for students to digest the materials taught in $40 \mathrm{~min}$. And then, it is hard for them to understand the concepts. It affects their collaboration, participation, and hence, their achievement on tests and exams. This might also be caused by the overloaded curriculum, through which teachers do not spend more time on a particular concept as they want to complete the scheme of work. Also, due to the overloaded timetable, they do not have sufficient time to prepare lessons. Students are therefore provided with insufficient knowledge, which does not facilitate skills construction.

Statements 6 and 10 representing students' creativity and innovation and students' ability to conduct research were the least improved compared to others. They were both rated by $29 \%$ of teachers questioned. The minor improvement can be associated with the lack of adequate materials and teaching aids in some schools leading to low levels of concept clarification which affects students' levels of critical thinking (Jane et al., 2020; Makunja, 2016). As a result, students fail to be innovative and creative due to inadequate knowledge and 
skills. In addition, many schools do not have sufficient computers for students; even those with smart rooms do not have access to the internet. These contribute more to the decrease in their ability to conduct research.

Apart from the proposed areas of improvement, teachers suggested some other areas that have been improved while using their preferred methods in teaching chemistry. These include students' curiosity and motivation, time management skills, working in the laboratory skills, and students' discipline, among others. The improvement in curiosity and motivation is probably because in some schools, students are allowed to manipulate some materials in the learning process and are curious about the next step to follow, which also improves their motivation to achieve the goal of the lesson.

Teachers were also asked if they have ever been trained on different methods of teaching chemistry; after joining the teaching profession, $73 \%$ have been trained on some teaching methods as they responded with yes, while $23 \%$ have not been trained as they responded wih no. Among the methods that they have been trained on including Learner-centered method, group discussion, inquiry-based method, ICT integration, Gender-sensitive, teaching mathematics and sciences methodologies, Mastery content, 5Es method, Project-based learning method, Pragmatic learning, Round corner method, $C B C, C P D$, think pair method, lesson preparation, and methods of conducting scientific research. Among the stated methods, some are not considered as teaching methods. For example, CBC, CPD, lesson preparation, and conducting scientific research are not teaching and learning methods. This might also be attributed to the lack of in-service training (Makunja, 2016). Therefore, more training are needed to provide clarification on teaching approaches, methods, and techniques.

Teachers whose responses were no were asked to suggest different methods they would like to be trained on to improve their chemistry teaching. These include: coaching and mentoring, laboratory experiment, teaching by using discrepant events during the teaching and learning process, how to search real examples to relate the chemistry lesson with our everyday life activities, practical work, video assimilation method, teaching chemistry through play, integrate ICT in teaching chemistry, evaluation method, remedial and coaching, group work, scientific research, learnercentered method, promotion of language acquisition, and improvising learning materials. Similarly, most teachers have not suggested the teaching methods they want to be trained on; rather, they only gave different topics they would like to be trained on. Few methods like laboratory-based method, role-play method, webbased method, and group discussion method were listed. This is because they are mostly known as the requirement of $\mathrm{CBC}$ implementation, and teachers need to be trained on them for effective teaching of chemistry that follows CBC principles.

The research intended to figure out the utilization of the instructional methods based on teachers' experiences. To respond to the third research question, data on teachers having more than five years of experience and those with less than five years of experience were filtered. Indeed, more than five years of teaching experience was chosen because the teachers in this range were hired before the 
implementation of CBC. The perception of teachers with more and less than five years of experience on their preferred methods of teaching chemistry is summarized in Figure 3.

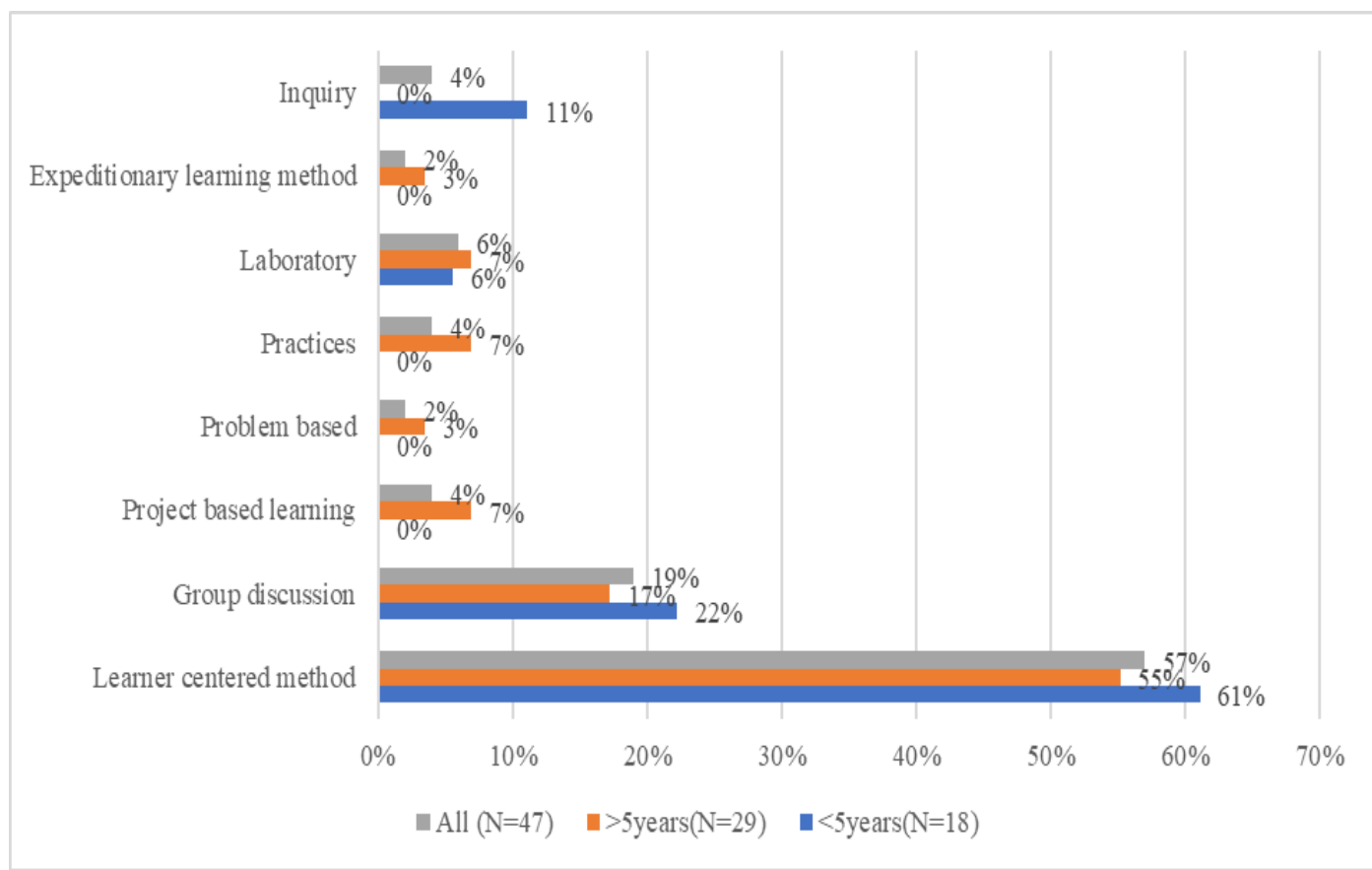

Figure 3: Teachers' Responses on the Most Preferred Chemistry Teaching Methods.

While splitting them into more and less than five years of experience and comparing their results in terms of experience, the Pearson chi-square test showed that there is no statistically significant difference (value: $25.33, d f: 16$, and $p: 0.064)$ between teachers with more than five years of experience and those with less than five years of experience. The results presented in Figure 3 showed that there are slight differences between teachers with less than five years of experience and those with more than five years of experience in their choice of the most preferred methods, though they are not statistically significant. For example, teachers with less than five years of experience rated the use of the learner-centered method at $61 \%$, while those with more than five years of experience rated them at $55 \%$. Also, teachers with less than five years of experience do not prefer methods like project-based learning, problem-based learning, and expeditionary learning method, while those with more than five years of experience do not choose the inquiry teaching method. This difference might be attributed to the resistance to change observed among experienced teachers (Ndihokubwayo et al., 2019). The results may also be biased to the small sample size used in this study. Therefore, further studies are recommended to consider a large sample size to supplement this study.

\section{Conclusion}

This study concludes that teachers prefer active teaching methods like group discussion method, laboratory-based method, problem-based method, projectbased method, among others. However, some teachers still use some practices of 
passive teaching methods. The study indicated the areas of improvement when teachers use their preferred methods. Classroom management is found to be highly improved. Students' conceptual understanding, students' achievement on tests and exams, students' collaboration skills, and students' participation, respectively are moderately improved. Students' creativity and innovation and students' ability to conduct research are found to be the least improved areas. The results of teachers in terms of experience showed no statistically significant difference between more experienced teachers ( $>5$ years) and less experienced teachers (<5years). In addition, teachers' misconception on teaching approaches, methods, and techniques is also found, and this is an alarming issue to consider as a priority. It is, therefore, recommended to the educational stakeholders to plan more pieces of training to address the problem.

From the consulted literature, it was found that many teachers claim the use of active teaching methods thoughthey do not apply them in the teaching process (Byusa et al., 2020a; Nsengimana et al., 2021). The findings from this study are in agreement with what has been found in the literature. However, the study's limitation lies on the fact that it was not possible to conduct observation in class to confirm whether the reported teachers preferred instructional methods aligned with what they do in the classroom. Therefore, future studies should conduct observation and interviews with teachers to obtain more data. Moreover, further studies should consider the secondary sources of data like lesson plans, schemes of work, and other pedagogical documents that could add more information. Similarly, students, schools' principles, and other school workers in the study should be taken into consideration for future studies.

\section{References}

Abanikannda, M. O. (2016). Influence of problem-based learning in chemistry on academic achievement of high school students in osun state, Nigeria. International Journal of Education, Learning and Development, 4(3), 55-63.

Abdi, A. (2014). The Effect of inquiry-based learning method on students' academic achievement in science course. Universal Journal of Educational Research, 2(1), 3741. https://doi.org/10.13189/ujer.2014.020104

Acar, B., \& Tarhan, L. (2007). Effect of cooperative learning strategies on students' understanding of concepts in electrochemistry. International Journal of Science and Mathematics Education, 5(2), 349-373. https://doi.org/https://doi.org/10.1007/s10763-006-9046-7

Aidoo, B., Boateng, S. K., Kissi, P. S., \& Ofori, I. (2016). Effect of problem-based learning on students' achievement in chemistry. Journal of Education and Practice, 7(33), 103-108.

Akani, O. (2015). Laboratory teaching: Implication on students' achievement in chemistry in secondary schools in the Ebonyi state of Nigeria. Journal of Education and Practice, 6(30), 206-213.

Alabi, A. O. (2014). Effect of activity-based teaching strategy on students' achievement of secondary school students in chemistry. Journal of Education and Policy Review, $6(2), 102-113$.

Alcott, B. (2017). Does teacher encouragement influence students' educational progress? A propensity-score matching analysis. Research in Higher Education, 58(7), 773804. https://doi.org/10.1007/s11162-017-9446-2 
Anyafulude, J. C. (2013). Effects of problem-based and discovery-based instructional strategies on students' academic achievement in chemistry. Journal of Educational and Social Research, 3(6), 105-112. https://doi.org/10.5901/jesr.2013.v3n6p105

Byusa, E., Kampire, E., \& Mwesigye, A. R. (2020a). Analysis of teaching techniques and scheme of work in teaching chemistry in Rwandan secondary schools. EURASIA Journal of Mathematics, Science and Technology Education, 16(6). https://doi.org/https://doi.org/10.29333/ejmste/7833

Byusa, E., Kampire, E., \& Mwesigye, A. R. (2020b). Ways school leaders support the teaching of chemistry. African Journal of Educational Studies in Mathematics and Sciences, 16(1), 63-72. https:// doi.org/10.4314/ajesms.v16i1.5

Chawla, J., \& Gurmit, S. (2015). Effect of concept mapping strategy on achievement of IX graders in relation to achievement motivation. Asia Pacific Journal of Research ISSN, 1(26), 53-65.

Fraenkel, R. J., Wallen, E. N., \& Hyun, H. H. (2012). How to design and evaluate research in education (8th ed.). Mc Graw Hill.

Frailich, M., Kesner, M., \& Hofstein, A. (2007). The influence of web-based chemistry learning on students' perceptions, attitudes, and achievements. International Journal of Phytoremediation, 25(2), 179-197. https://doi.org/10.1080/02635140701250659

Gabel, D. (1999). Improving teaching and learning through chemistry education research: A look to the future. Journal of Chemical Education, 76(2-4), 548-554. https://doi.org/10.1021/ed076p548

Gill, A. K., \& Kusum. (2017). Teaching approaches, methods, and strategy. Scholarly Research Journal for Interdisciplinary Studies, 4(36). https://doi.org/10.21922/srjis.v4i36.10014

Hailikari, T., Katajavuori, N., \& Lindblom-ylanne, S. (2008). The relevance of prior knowledge in learning and instructional design. American Journal of Pharmaceutical Education, 72(5). https://doi.org/10.5688/aj7205113

Jack, G. U. (2013). Concept mapping and guided inquiry as effective techniques for teaching difficult concepts in chemistry: Effect on students' academic achievement. Journal of Education and Practice, 4(5), 9-15.

Jane, A., Dinah, W., \& Irene, A. (2020). The teacher-parent nexus in the competencybased curriculum success equation in Kenya. International Journal of Educational Administration and Policy Studies, 12(1), 60-76. https:// doi.org/10.5897/ijeaps2020.0646

Kanadli, S. (2016). A meta-analysis on the effect of instructional designs based on the learning styles models on academic achievement, attitude, and retention. Educational Sciences: Theory \& Practice, 16(6), 2057-2086. https:// doi.org/10.12738/estp.2016.6.0084

Khan, M. S., Hussain, S., Ali, R., Majoka, M. I., \& Ramzan, M. (2011). Effect of inquiry method on achievement of students in chemistry at the secondary level. International Journal of Academic Research, 3(1), 955-959.

Kousa, P., Kavonius, R., \& Aksela, M. (2018). Low-achieving students' attitudes towards learning chemistry and chemistry teaching methods. Chemistry Education Research and Practice, 19(2), 431-441. https://doi.org/10.1039/C7RP00226B

Makunja, G. (2016). Challenges facing teachers in implementing competence-based curriculum in Tanzania: The case of community secondary schools in Morogoro Municipality. International Journal of Education and Social Science, 3(5), 30.

Ndayambaje, I. (2018). Effect of supervision on timely completion of Ph.D. programme. Rwandan Journal of Education, 4(2), 57-70.

Ndihokubwayo, K., Habiyaremye, H. T., \& Rukundo, J. C. (2019). Rwandan new 
competence base: Curriculum implementation and issues; sector-based trainers. A Journal of Contemporary Research, 16(1), 24-41.

Ndihokubwayo, K., Uwamahoro, J., \& Ndayambaje, I. (2020). Implementation of the competence-based learning in Rwandan physics classrooms: First assessment based on the reformed teaching observation protocol. EURASIA Journal of Mathematics, Science and Technology Education, 16(9). https:// doi.org/10.29333/ejmste/8395

Nsengimana, T., Habimana, S., \& Mutarutinya, V. (2017). Mathematics and science teachers' understanding and practices of learner-centered education in nine secondary schools from three districts in Rwanda. Rwandan Journal of Education, $4(1), 55-68$.

Nsengimana, T., Mugabo, L. R., Ozawa, H., \& Nkundabakura, P. (2021). Science competence-based curriculum implementation in Rwanda: A multiple case study of the relationship between a school's profile of implementation and its capacity to innovate. African Journal of Research in Mathematics, Science and Technology Education, 0(0), 1-14. https://doi.org/10.1080/18117295.2021.1888020

Nsengimana, T., Mugabo, R. L., Hiroaki, O., \& Nkundabakura, P. (2020). Reflection on science competence-based curriculum implementation in Sub-Saharan African countries. International Journal of Science Education, Part B: Communication and Public Engagement, 0(0), 1-14. https:// doi.org/10.1080/21548455.2020.1778210

Nsengimana, V. (2021). Implementation of competence-based curriculum in Rwanda: Opportunities and challenges. Rwandan Journal of Education, 5(1), 129-138.

Olakanmi, E. E. (2008). The effect of web-based computer simulation on students' conceptual understanding of the rate of reaction and attitude towards chemistry. Journal of Baltic Science Education, 14(5), 627-640.

Olarewaju, A., \& Awofala, A. (2011). Effect of concept mapping strategy on students' achievement in junior secondary school mathematics. International Journal of Mathematics Trends and Technology, 2(3), 11-16. http://www.internationaljournalssrg.org

Olatoye, R. A., Aderogba, A. A., \& Aanu, E. M. (2011). Effect of co-operative and individualized teaching methods on senior secondary school students ' achievement in organic chemistry. The Pacific Journal of Science and Technology, 12(2), 310-319.

Oludipe, D., \& Awokoy, J. O. (2010). Effect of cooperative learning teaching strategy on the reduction of students' anxiety for learning chemistry. Journal of Turkish Science Education, 7(1), 30-36.

Rawlusyk, P. E. (2018). Assessment in higher education and student learning. Journal of Instructional Pedagogies, 21, 1-34.

Sing, I. S., \& Moono, K. (2015). The effect of using concept maps as study tools on achievement in chemistry at tertiary level. Journal of Education and Practice, 6(15), 106-116.

Stiggins, R. (2002). Assessment crisis: The absence of assessment for learning. Phi Delta Kappan, 83(10), 1-10. https://engageny.org/sites/default/files/resource/attachments/assessmentcri sis.pdf\%5Cnhttp://www.edtechpolicy.org/CourseInfo/edhd485/AssessmentC risis.pdf

Sudha, A., \& Amutha, S. (2015). Higher secondary learners' effectiveness towards webbased instruction (WBI) on chemistry. Universal Journal of Educational Research, 3(7), 463-466. https://doi.org/10.13189/ujer.2015.030706

Suhag, A. K., Lashari, A. A., Abdul, M., \& Ahmed, M. F. (2018). Analyzing the effects of science teaching methods on students' achievement: A study of secondary 
school teachers of district Khairpur Mir's. Journal of Social Sciences and Media Studies, 1(2), 27-33.

Tatli, Z., \& Ayas, A. (2013). Effect of a virtual chemistry laboratory on students ' achievement. Journal of Educational Technology \& Society, 16(1), 159-170. https://www.jstor.org/stable/jeductechsoci.16.1.159

Tuysuz, C. (2010). The effect of the virtual laboratory on students' achievement and attitude in chemistry. International Online Journal of Educational Sciences, 2(1), 3753.

Uwizeyimana, D., Yadav, L., Musengimana, T., \& Uwamahoro, J. (2018). The impact of teaching approaches on effective physics learning: An investigation conducted in five secondary schools in Rusizi district, Rwanda. Rwandan Journal of Education, 4(2), 4-14.

Yunus, F. W., \& Ali, Z. M. (2018). Attitude towards learning chemistry among secondary school students in Malaysia. Asian Journal of Behavioural Studies, 3(9), 63-70. https://doi.org/10.21834/ajbes.v3i9.61

Yusuf, A. (2004). Effect of cooperative instructional strategy on students ' performance in social studies. Nigerian Journal of Social Studies, 8(2), 23-36. 